\title{
Peran Pesantren sebagai Salah Satu Lembaga Pendidikan Islam
}

\author{
Indah Herningrum ${ }^{1}$, Muhammad Alfian ${ }^{2}$, dan Pristian Hadi Putra ${ }^{3}$ \\ ${ }^{1}$ Program Studi Pendidikan Agama Islam, Institut Agama Islam Negeri (LAIN) Kerinci \\ 1,2 Program Studi Pendidikan Agama Islam, LAIN Kerinci \\ e-mail: indahherningrum $@$,iainkerinci.ac.id
}

\begin{abstract}
ABSTRAK. Salah satu lembaga pendidikan Islam yang telah lama berkembang dan berakar kuat tradisinya adalah pesantren. Namun, nama pesantren sempat tercoreng namanya dengan dikaitkan sebagai asal muasal paham radikalisme di Indonesia, yang masih berupa isu semata. Oleh karenanya, menarik untuk diteliti dan diketahui mengenai berbagai sepak terjang pesantren di Indonesia dengan tradisi keislamannya serta kontribusi lainnya diranah pembentukan moral Islam, serta dalam ranah social serta ekonomi dalam ranah umumnya. Pesantren telah banyak berjasa dalam pembentukan pribadi serta daerah yang kental dengan tradisi ke Islaman. Awalnya hanya beroperasi pada sekitar "pinggiran desa", meluas hingga berkembang keseluruh negeri. Perannya tidak hanya itu, dalam hal social ekonomi pun, lembaga pesantren berusaha hadir dan mengembangkan kosep-konsep brilian yang mampu menjawab masalah kesejahteraan masyarakat sekitarnya secara khusus, dan Indonesia secara umum.
\end{abstract}

Kata kunci: pesantren, kontribusi, moral, sosial, ekonomi

\section{PENDAHULUAN}

Pendidikan dewasa ini mengemban tugas yang lebih berat, dimana semakin majunya teknologi informatika mengakibatkan degradasi moral semakin kentara saja. Kita tidak bisa disatu sisi menyalahkan arus globalisasi informatika, karena disadari seiring berkembangnya zaman, perkembangan akan teknologi tak bisa terhindarkan, mengingat manusia semakin hari semakin berpikir untuk "memudahkan" semua proses hidupnya di dunia ini. Namun, seperti hal yang tersebut diatas, hal ini menyebabkan degradasi moral yang tak terhindarkan pula, yang menjadikan manusia "melek" teknologi, namun kosong "moral" nya.

Bukan hanya pendidikan secara umum yang mengemban tugas mulia untuk membimbing "moral" ini ke arah yang lebih baik, namun lebih dari itu, pendidikan agama (dalam hal ini agama Islam) merasa mempunyai kewajiban untuk mengemban tugas ini, terlebih pembentukan moral dan budi yang mulia merupakan tujuan dari di adakannya pendidikan agama (pun pendidikan nasional secara umum).( UU RI No. 20 Tahun 2003)

Pendidikan keagamaan Islam berbentuk pendidikan diniyah dan pesantren (PP No. 55 Tahun 2007: Pasal 14), menyiratkan bahwa dua bentuk lembaga pendidikan Islam ini pun mempunyai peran untuk membimbing moral ini sesuai dengan apa yang ada dalam ajaran Islam. Namun, terjadi hal yang sedikit mengagetkan dimana tren yang berkembang dalam dunia Islam beberapa tahun belakangan ini adalah fenomena radikalisme pemikiran keagamaan pada lembagalembaga pendidikan seperti pesantren, madrasah dan sekolah. Hal ini dibuktikan oleh kasus-kasus terorisme dan kekerasan yang pada umumnya dilakukan oleh orang-orang yang merupakan 
keluaran dari lembaga pendidikan Islam dan memiliki motivasi ideology Islam yang kental, dimana ideology tersebut juga merupakan produk doktrin agama (Abdurrohim, Disertasi: 2014, 2).

Menyikapi hal yang kontradiktif ini, dimana lembaga pendidikan Islam seharusnya menjadi pembimbing moral, namun ada beberapa yang "kebablasan" dalam memberikan doktrin keagamaan, sehingga memiliki moralitas yang "lebih tinggi" dari kadarnya, maka penulis merasa perlu untuk mengkaji tentang sejauh mana kontribusi sebenarnya yang telah ditorehkan oleh lembaga pendidikan Islam ini (dalam hal ini dikhususkan pesantren) dalam perjalanannya sebagai lembaga keagamaan Islam yang saat ini telah diakui pemerintah.

\section{PEMBAHASAN}

\section{Pesantren Sebagai Lembaga Pendidikan Islam}

M. Arifin (1993: 11) menyatakan, dalam masyarakat yang selalu bergerak arah kehidupannya, pendidikan disebut memiliki peranan penting dalam menentukan jati diri dan perubahan masyarakat tersebut, karena pendidikan sendiri merupakan sebuah usaha sistematis guna melestarikan, mengalihkan juga mentransformasikan nilai-nilai kebudayaan dalam segala bentuk dan jenisnya kepada para generasi penerus, demikian pula halnya dengan pendidikan Islam.

Secara umum, bisa disebutkan bahwa pendidikan Islam bisa dikatakan sebagai usaha untuk mengembangkan potensi yang dimiliki manusia, baik jasmani maupun rohani kearah yang lebih baik dengan menggunakan ajaran yang terdapat dalam Islam.

Apabila kita menelusuri perjalanan sejarah pendidikan Islam di Indonesia sampai ke masa lampau, akan sampai pada penemuan bahwa pesantren adalah salah satu bentuk indigenous culture, atau bentuk kebudayaan asli bangsa Indonesia, ${ }^{1}$ sebab lembaga pendidikan dengan pola kyai, santri dan asrama telah dikenal dalam kisah dan ceritera rakyat, maupun dalam sastra klasik Indonesia, khususnya dipulau Jawa (Abdurrahman Saleh, 2000: 221). Pondok pesantren tidak tumbuh begitu saja, namun tumbuh sedikit demi sedikit.

Semula, pondok pesantren lebih dikenal sebagai lembaga pendidikan Islam: lembaga yang digunakan untuk menyebarkan dan mempelajari agama Islam. Agama Islam mengatur bukan hanya amalan-amalan peribadatan, juga bukan sekedar hubungan orang dengan tuhannya, melainkan juga peri kelakuan orang dalam berhubungan dengan sesama dan dunianya. Hal-hal ini segera pula berpengaruh terhadap usaha-usaha pondok pesantren untuk menghasilkan pemuka-pemuka dalam kehidupan kemasyarakatan. Gerakan bagi penyebaran agama, gerakan bagi pemahaman kehidupan keagamaan, dan gerakan-gerakan sosial berpadu dalam pekerjaan pondok pesantren. Kemampuan pondok bukan hanya dalam membina pribadi muslim,

${ }^{1}$ Sebagai Lembaga Indigenous, Pesantren Memperlihatkan Dirinya Seperti Orang Melihat Lembaga "Gotong Royong", Yang Dikatakan Sebagai Ciri Khas, Bagian Dari Tradisi Dan Merupakan Hal Yang "Asli Indonesia", Yang Merefleksikan Ola Kulturil Masyarakat Indonesia.Lembaga Pondok Tidak Dilihat Sebagai Salah Satu Manifestasi Dari KeIslaman, Melainkan Dilihat Pula Sebagai Sesuatu Yang "Bersifat Indonesia" Karena Sebelum Datangnya Islam Ke Indonesia, Lembaga Pondok Sudah Ada Di Indonesia. Jelasnya, Lembaga Pesantren Merupakan Hasil Penyerapan Akulturasi Dari Masyarakat Indonesia Terhadap Kebudayaan Hindu-Budha Dan Kebudayaan Islam Yang Menghasilkan Sesuatu Yang Khas Indonesia, Yang Berbeda Dengan Yang Ada Di Arab Maupun India. M. Dawam Raharjo, Dunia Pesantren Dalam Peta Pembaharuan, (Dalam, Pesantren Dan Pembaharuan, (Pt. Pustaka Lp3es: Jakarta, 1995) Hlm 9). 
melainkan juga usaha untuk mengadakan perubahan dalam sosial kemasyarakatan. Peran pondok pesantren bukan hanya dilihat dari transformasi kehidupan santri dan alumninya semata, melainkan juga kehidupan masyarakat sekitarnya.

Kedudukan seperti ini membawa akibat: di satu pihak memanfaatkan sebesar-besarnya potensi pondok, dilain pihak bagaimana membatasi potensi yang sedemikian ini. Pengaruh dan kesadaran terhadap potensi ini pada mulanya berasal dari peneliti penelitian sosial. Publikasi para peneliti ini kemudian mempengaruhi pihak-pihak yang berkepentingan. Di zaman para wali, di zaman kerajaan Islam jawa, di zaman pergolakan melawan penjajahan, masa-masa revolusi kemerdekaan, bahkan pada masa orde baru sekitar tahun 1966, peranan pondok pesantren bagi perubahan social kelihatan jelas ${ }^{2}$. Di saat-saat seperti ini, nampaknya fungsi pesantren sebagai lembaga social itu lebih menonjol dibandingkan dengan fungsi pendidikannya. Pembangkitan kembali (revitalisasi)masyarakat dan bangsa dapat mengambil pelajaran dari masa-masa tersebut. Disini, dapat dikatan bahwa pondok pesantren telah melaksanakan fungsinya membangun pribadi dan masyarakat.

Habib Chirzin (1995: 87), menyatakan bahwa pesantren dengan ruh, sunnah dan kehidupan berasrama dengan kyai sebagai tokoh pokoknya dan masjid sebagai pusat lembaganya, merupakan suatu sistem pendidikan yang tersendiri dan mempunyai corak khusus. Di dalam ruh, sunnah dan kehidupan berasrama itulah antara lain letak kekhususan pondok sebagai suatu sistem pendidikan. Adapun metode pengajaran yang dipakai dalam diskursus perkembangan pesantren, jika ditilik lebih jauh sebenarnya bisa menggunakan metode pembelajaran modern yang aktual dan dinamis, namun dikebanyakan pesantren, masih memakai metode tradisional, unik dan menjadi ciri khas pengajaran di pesantren yaitu wetonan dan sorogan.

Metode wetonan adalah metode pembelajaran yang pengaplikasiannya berbentuk pembelajaran tatap muka antara kyai sebagai pusat belajar, dan santri sebagai objek pembelajarannya. Dalam metode ini, santri duduk mengelili kyai guna mendengarkan bahasan dari kitab tertentu yang dibawakan oleh kyainya. Kemudian, jika ada beberapa poin penting yang disampaikan oleh kyainya, santri kemudian mencatatnya dalam kitab masing-masing, sebutan "weton" berasal dari bahasa jawa dan identik sebutannya untuk pesantren dijawa timur. Di jawa barat, metode ini disebut dengan istilah bandongan, sedang di sumatera disebut dengan istilah halaqah. Adapun metode sorogan ialah santri menghadap kyai satu persatu secara personal, dengan membawa kitab masing-masing. Kyainya membacakan pelajaran berbahasa arab itu

${ }^{2}$ Betapapun Juga, Pesantren-Pesantren Yang Jumlahnya Amat Besar Itu Mempunyai Fungsi Tertentu Dalam Proses Perkembangan Masyarakat, Setidak-Tidaknya Dalam Proses Sosialisasi Anggota-Anggota Masyarakat, Terutama Pada Masyarakat Indonesia "Zaman Dulu" Atau Masyarakat Pedesaan Yang Terbelakang, Terpencil, Atau Masyarakat Di Sekeliling Tempat Dimana Lembaga Itu Berada. Pesantren Menampung Anak-Anak Muda Yang Tidak Tertampung Pada Lembaga-Lembaga Pendidikan Klasikal Yang Ada, Karena Kemiskinan Kehidupan Orang Tua Mereka, Yang Menyebabkan Mereka Tidak Bisa Bersekolah, Maka Lewat Pendidikan Tradisionil Dari Pesantren-Pesantren, Setidak-Tidaknya Akan Memperoleh DasarDasar Pendidikan Yang Rasa-Rasanya Cukup Dan Bermanfaat Menghadapi Lingkungan Dan Perjalanan Hidupnya. Mereka Yang Telah Mendapatkan Pendidikan Dari Pesantren Tidak Mungkin Akan Menyembah Api Atau Pohon, Bermabuk-Mabukan, Mencuri, Berzina, Serta Akan Berusaha Pula Untuk Memiliki Budi Yang Luhur Dalam Pergaulannya Dengan Orang Tua, Kawan, Tamu, Pemimpin, Orang Miskin, Ataupun Kaya. Mereka Yang Berada Dalam Lingkungan Pesantren Memang Mempelajari Agama, Namun Dalam Paham Keagamaan Itu Mereka Secara Sadar Mengetahui Adanya Pengertian "Ilmu”, Sesuatu Yang Merupakan Pangkal Tolak Dari Penguasaan Manusia Pada Alam Fisik Dan Lingkungan Sosialnya. M. Dawam Raharjo, Dunia Pesantren Dalam Peta Pembaharuan, (Dalam, Pesantren Dan Pembaharuan, Hlm. 4) 
kalimat demi kalimat menyimak dan menterjemahkannya, dan menerangkan maksudnya. Santri menyimak dan mengesahkan, kemudian mencatat hal-hal penting yang disampaikan oleh kyai dalam ketab yang dibawanya. Adapun istilah sorogan ini berasal dari kata sorog (jawa) yang berarti menyodorkan (memberikan) kitabnya di hadapan kyai atau pembantunya (Abdurrachman Saleh, 2000: 223).

Dalam metode pengajaran bentuk wetonan dan sorogan ini, tidak ada pengulangan pelajaran ataupun pertanyaan yang diajukan oleh kedua belah pihak, dan setiap pelajaran dimulai dengan bab yang baru. Semua pelajaran ini diberikan oleh kyai atau pembantunya yang disebut badal (pengganti) atau qari' (pembaca) yang terdiri dari santri senior. Kenaikan tingkat ditandai dengan bergantinya kitab yang dipelajari (Habib, 1995: 88).

Sementara beberapa pondok pesantren berjalan dengan tradisi yang diwarisinya secara turun-temurun tanpa adanya variasi dan perubahan, ada satu dua yang mencoba mencari jalan sendiri yang diharapkan akan menghasilkan lebih banyak dalam waktu yang lebih singkat. ${ }^{3}$ Pesantren semacam ini menyusun kurikulumnya berdasar pemikiran akan kebutuhan anak didik dan masyarakat. Untuk itu mereka mengintrudusir beberapa cabang ilmu pelengkap seperti sejarah, berhitung, ilmu aljabar, ilmu bumi, ilmu ukir, ilmu alam, ilmu hayat, tata bahasa dan beberapa bahasa asing. Metode wetonan san sorogan mulai ditinggalkan atau didampingi dengan sistim madrasi atau klasikal dengan menggunakan alat peraga, evaluasi dengan berbagai macam variasinyadan juga latihan-latihan. Prinsip-prinsip psikologi perkembangan dalam pendidikan dalam proses belajar mulai di terapkan, dan metode pengajaran baru pada masing-masing fakultas dipraktekan. Kenaikan tingkat, pembagian kelas dan pembatasan masa belajar diadakan sembari administrasi sekolahpun dilaksanakan dalam organisasi yang tertib.

Dalam kaitannya dengan hal diatas, maka ada beberapa peneliti yang berusaha melakukan kategorisasi terhadap pesantren ini. Dipandang dari kemajuan berdasarkan muatan kurikulumnya, martin van bruinessen mengelompokan pesantren menjadi pesantren paling sederhana yang hanya mengajarkan cara membaca huruf arab dan menghafal beberapa bagian atau seluruh alQur'an, pesantren sedang yang mengajarkan berbagai kitab fiqh, ilmu akidah, tata bahasa arab (nahwu sharaf), terkadang amalan sufi, dan pesantren paling maju yang mengajarkan kitab-kitab fiqh, aqidah, dan tasawuf yang lebih mendalam dan beberapa mata pelajaran tradisional lainnya.

Dhofier (1985: 41) memandang dari perspektif keterbukaan terhadap perubahanperubahan yang terjadi, kemudian membagi pesantren menjadi dua kategori, yaitu pesantren salafi dan khalafi. Pesantren salafi tetap mengajarkan pengajaran kitab-kitab Islam klasik sebagai inti pendidikannya, dengan memakai metode sorogan. Sedangkan pesantren khalafi telah mengembangkan pengajaran ilmu-ilmu umum, atau dengan membuka model sekolah umum didalam lingkungan pesantren.

${ }^{3}$ Dari Sini Muncul Macam Pembagian Pondok Pesantren Yaitu: (1) Pondok Pesantren Yang Para Santrinya Belajar Dan Bertempat Tinggal Di Asrama Lingkungan Pesantren Dengan System Pengajarannya Yang Berlangsung Dengan Wetonan Dan Sorogan, (2) Pondok Pesantren Yang Menyelenggarakan Pengajarannya Secara Klasikal (Madrasah/Sekolah Bahkan Ada Yang Sampai Perguruan Tinggi). Peranan Kyai Memberikan Pengajaran Dan Bimbingan Ibadah. Para Santri Bertempat Tinggal Di Asrama, (3)Pondok Pesantren Yang Hanya Merupakan Asrama, Sedangkan Para Santri Belajar Di Madrasah Atau Sekolah Umumdan Kyai Memberikan Pelajaran Agama Dan Pembinaan Mental Serta Bimbingan Ibadah Yang Kegiatannya Dipusatkan Dimasjid. (Baca Abdul Ranchman Shaleh, Pendidikan Agama Dan Keagamaan..., HIm 224). 
Di sisi lain, ada juga yang membagi pesantren menjadi lima kelompok, yang berdasarkan pada keberadaan kyai, santri, serta sarana dan prasarana yang mendukungnya, yaitu: kelompok pertama, pesantren yang hanya terdiri dari masjid dan rumah kyai; kelompok kedua yaitu pesantren yang terdiri dari masjid, rumah kyai, dan pondok (asrama); kelompok ketiga yaitu pesantren yang terdiri dari masjid, rrumah kyai, pondok (asrama), dan pendidikan formal; keempat, yang memiliki masjid, rumah kiai, pondok (asrama), pendidikan formal, dan pendidikan keterampilan; dan yang kelima yaitu pesantren yang memiliki masjid, rumah kiai, pondok (asrama), madrasah, pendidikan formal serta ketrampilan dan bangunan-bangunan fisik lainnya yang mendukung kinerja pesantren (Marwan Saridjo, 1982: 10)

Pesantren masih dapat dikelompokan kedalam begian-bagian tertentu lagi, bila diteropong dari pengamatan aspek lainnya, seperti pesantren kota dan pesantren kota, pesantren milik pribadi kiai dan pesantren milik yayasan dan sebagainya. Namun dari kesemua kategorisasi yang disebut diatas, tidak bisa terlepas dari unsur utama pesantgren yaitu kyai (dalam hal ini sebagai pemilik dan pembimbing), santri, masjid (dan bangunan lainnya), juga system pendidikan yang dikembangkannya.

\section{Peran Pesantren Sebagai Lembaga Pendidikan Islam}

Setelah kita mengetahui bagaimana seluk beluk pesantren mulai dari sejarah terbentuknya hingga pada beragam modelnya, kita memasuki bahasan selanjutnya yaitu mengenai kontribusi konkrit yang diberikan pesantren sesuai dengan kedudukannya sebagai salah satu lembaga pendidikan Islam.

Sebagai mana tertulis dalam peraturan pemerintah nomor 55 tahun 2007, pesantren memiliki tujuan untuk menanamkan keimanan dan ketakwaan kepada Allah SW'T, akhlak mulia, serta tradisi pesantren untuk mengembangkan kemampuan, pengetahuan, dan keterampilan peserta didik untuk menjadi ahli ilmu agama Islam (mutafaqqih fiddin) dan/atau menjadi muslim yang memiliki keterampilan/keahlian untuk membangun kehidupan yang Islami di masyarakat. Namun, tak bisa dipungkiri, selain dari pencapaian tujuan diatas, pesantren baik langsung maupun tidak langsung telah mencatatkan beberapa kontribusi penting, dalam perjalanannya selama beberapa abad keberadaannya di negeri ini. Adapun kontribusi-kontribusi pesantren berdasarkan kepada tujuan pesantren seperti yang tersebut dalam PP No. 55 Tahun 2007 adalah:

- Peran Pesantren Dalam Menanamkan Ketakwaan Kepada Allah SWT Serta Pembentukan Ahlak Mulia

Dengan keberadaannya selama beberapa abad silam, pesantren dibangun dengan tujuan utama untuk memberikan pendidikan agama Islam kepada masyarakat sekitar tempat didirikannya pesantren tersebut. Dalam perjalanan pengajarannya, hal yang paling utama ditekankan adalah bagaimana membentuk sikap Iman dan takwa pada peserta didiknya (santri), sebagai bekal awal dalam perjalanan pendidikan dan pemberian materi setelahnya, karena dari sikap iman dan takwa, akan bisa lebih mudah membentuk sikap lainnya.

Lebih lanjut, Pesantren sangat disadari juga menjadi "basis" pembentukan ahlak dan moral anak bangsa yang Islami. Hal ini tidak bisa dipungkiri dari pola pembinaan pesantren yang kelihatannya "memaksakan" santrinya untuk taat dan pada peraturan pesantren, mulai 
dari bangun pada dini hari untuk tahajud, taat pada waktu shalat wajib, harus taat pada Pembina, terlebih pada kyai, dilarangnya membawa alat komunikasi yang up to date, juga pemberian materi agama yang sistematis, semakin mendukung peran pesantren sebagai benteng pertahanan moral.

Oleh karenanya, sekedar untuk menjadi pegangan operatif, dalam mengembangkan pendidikan watak dan karakter, sejumlah nilai-nilai keagamaan yang mendasar perlu ditanamkan. Nilai-nilai keimanan, ke-Islaman, jiwa ihsan, ketaqwaan, sikap ikhlas, tawakkal, syukur, dan sabar serta nilai-nilai akhlaqul karimah (seperti, silaturrahim, ukhuwwah, almusawah, adl, husnudzdzan, tawadhu, al-wafa ', amanah, al-iffah atau ta 'affuf dan lainnya) sebagai nilai-nilai keagamaan yang mendasar tentu akan menjadi bagian terpenting dalam pendidikan watak dan karakter.

Sebuah bangsa akan dinyatakan sebagai bangsa yang "maju" tidak semata-mata disebabkan oleh kompetensi, teknologi canggih ataupun kekayaan lainya, tetapi yang paling utama karena dorongan semangat dan karakter bangsanya. Oleh karena itu, dapat diibaratkan bahwa watak dan karakter laksana kemudi bagi sebuah kapal. Watak dan karakter adalah kemudi hidup yang akan menentukan arah yang benar bahtera kehidupan bangsa. Sebaliknya, jika kemudi ini di arahkan pada arah yang salah, maka akan hancurlah bangsa itu.

- Peran Pesantren Dalam Menghasilkan Ahli Ilmu Agama Islam

Dari waktu ke waktu, bahkan telah berabad lamanya, pesantren telah menunjukan dirinya sebagai basis pendidikan keagamaan yang tangguh, pesantren telah membuktikan dirinya pula sebagai produsen ulama yang belum tertandingi oleh lembaga pendidikan lain manapun dinegeri ini. Namun demikian, ada ironi yang terjadi dimana, semakin banyak munculnya pesantren di Indonesia, namun jumlah ulama yang kharismatik karena ilmunya serta kualitas ahlaknya semakin berkurang. Setelah sebagian mereka wafat dan belum tergantikan secara memadai oleh generasi penerus yang memiliki kualitas individu dan keulamaan sebagaimana pendahulunya (Suryadharma Ali, 2013: 21).

Namun, dengan diperlakukannya undang-undang nomor 55 tahun 2007 tentang pendidikan agama dan keagamaan, memungkinkan pemerintah memberikan dukungan yang semakin besar baik berupa kebijakan, program, finansial maupun bentuk lainnya kepada pesantren. Dukungan ini harus memperkuat pesantren dalam meningkatkan peran dan memperbesar kontribusinya dalam menghasilkan ulaama dan generasi masyarakat yang berkarakter, tangguh dan maju.

Sejalan dengan hal ini, ginanjar kartasasmita, dalam penyampaiannya pada pada kegiatan Milad Pondok Pesantren Al Qur'an Al Falah yang ke-29, menyatakan banwa perkembangan SDM akan dengan sendirinya terjadi sebagai hasil dari interaksi antara pertumbuhan ekonomi, perubahan sosial budaya termasuk kedalaman pengamalan ajaran dan nilai-nilai agama serta perkembangan iptek. Apabila dilaksanakan secara terencana dan terkendali, ketiga proses tersebut menjadi sinergistik. Dalam hal ini pembangunan ekonomi tidak secara otomatis menjamin terdapatnya peningkatan kualitas SDM. Namun perkembangan SDM yang berkualitas dapat mempercepat pertumbuhan ekonomi. Setelah kita telusuri peluang dan tantangan untuk meningkatkan kualitas SDM sampailah kita pada harapan pada upaya peningkatan SDM melalui pondok pesantren. 
Lanjutnya, Untuk mewujudkan harapan tersebut di atas kunci utamanya terletak di tangan para pendidik, yang harus memiliki karakter kuat, sabar, istiqomah, tegas, penuh perhatian, adil, menguasai benar-benar materi yang ingin disampaikan. Guru yang sadar benar bahwa anak didik bukan sekedar titipan orangtunya untuk dididik menjadi manusia yang memiliki ahlak mulia, tetapi lebih tinggi lagi adalah amanah dari Allah SWT. Di sini terasa benar betapa berat tugas seorang guru. Sekali salah didik sulit diperbaiki lagi, karena tahapan umur anak-anak mempunyai kekhususan tersendiri. Anak didik kita sebagai kertas putih sekali sudah tercoreng tinta, sulit dapat dihapus. Tuntutan jaman menghendaki agar pembentukan kepribadian harus dilakukan secara lebih seksama, sehingga SDM diarahkan untuk menghadapi tantangan jaman dan di waktu yang bersamaan menjadi insan yang taat menjalankan ajaran agamanya. Dengan perkataan lain Pondok Pesantren harus dapat turut mewujudkan manusia Indonesia yang beriman dan bertaqwa, yang berilmu dan beramal; juga manusia Indonesia yang modern.

- Peran Pesantren Sebagai Perintis Lingkungan Agama yang islami

Seperti yang telah di uraikan dalam bahasan sebelumnya, pesantren yang merupakan lembaga pendidikan Islam yang mula-mula muncul di nusantara, berperan penting sebagai sarana pembangunan dan pengembangan religiusitas masyarakat sekitarnya, pun dalam hal ini Indonesia secara umum (karena seiring berkembangnya waktu, pesantren mulai meluas bukan hanya di jawa.

Pada masa-masa perkembangannya, pesantren dijadikan sebagai pilihan terakhir bagi masyarakat tak mampu untuk "menitipkan" anaknya pada kyai, dengan tujuan agar setidaknya anaknya nanti mendapatkan pendidikan, walaupun sekedar pendidikan agama, karena keadaan yang tidak memungkinkan dibawanya anak tersebut pada lembaga pendidikan umum. Dalam lingkup pendidikannya pada saat itu, pesantren mendidik anakanak titipan ini dengan berbagai macam kitab kuning, mendidiknya untuk menghafal Qur'an, mendidiknya untuk berdisiplin ilmu, yang setelah sekembalinya dari pesantren, anak ini akan menjadi guru agama, sekaligus membuktikan bahwa lulusan pesantren bukannya tanpa ilmu yang berarti.

Berkaitan dengan hal diatas, dengan keberadaan pesantren secara tidak langsung juga membawa pengaruh yang signifikan terhadap perubahan terhadap perubahan kehidupan keagamaan di lingkungan sekitar pesantren (bukan hanya menjadi tempat titipan anak bagi masyarakat sekitarnya untuk belajar).

Studi kasus dapat ditunjukan, yaitu sejarah pertumbuhan pesantren tebu ireng di jombang. Masyarakat pedesaan pada saat itu mulanya adalah sebuah masyarakat serba keduniawian (mundaan) yang didukung oleh kehidupan yang relatif makmur dengan adaya sebuah pabrik gula di salah satu pedukuhan desa itu. Sikap hidup masyarakat Jawa lama, yang berorientasi pada harmoni dengan sang pencipta dalam suatu kehidupan yang serba keagamaan, bersinggungan dengan ekses-ekses dari kehidupan ekonomi liberal yang mendukung eksistensi pabrik gula itu. Proses akulturasi hasil perbenturan ini menciptakan masyarakat yang secara budaya berwatak rawan: hilangnya rasa aman perorangan dari gangguan "jago-jago" dan meluasnya relativitas moral. Berdirinya sebuah pesantren di tempat ini, pada mulanya memperoleh tantangan keras dari masyarakat, tetapi lambat laun masyarakat itu mulai mengalami transformasi menjadi sebuah pola kehidupan yang baru, di 
mana nilai kehidupan beragama mulai mendapatkan tempat yang dominan (Dawam Rahardjo, 1995: 43). Hal ini menjadi bukti, bahwa keberadaan pesantren di sebuah lingkungan tertentu, memberikan pengaruh yang cukup dominan dalam pembentukan keagamaan di lingkungan tersebut.

- Peran Pesantren Dalam Pembentukan Lingkungan Sosial dan Ekonomi

Sejak awal kelahirannya, pesantren tumbuh, berkembang, dan tersebar diberbagai desa dan kelurahan di daerah jawa. Keberadaan pesantren sebagai lembaga keislaman yang sangat kental dengan karakteristik Indonesia (indigenous culture) ini memiliki nilai-nilai strategis dalam pengembangan masyarakat Indonesia.

Realitas menunjukan, pada satu sisi, sebagian besar penduduk Indonesia terdiri dari umat Islam, dan pada sisi lain, mayoritas dari mereka tinggal di pedesaan (Abd, A’la, 2006: 1). Pondok pesantren selain sebagai lembaga pendidikan keagamaan (tafaqquh fiddin) juga berfungsi sebagai lembaga pengembangan sosial masyarakat, karena tumbuh dan berkembangannya berada ditengah-tengah masyarakat.

Pengembangan potensi sosial diarahkan pada keamampuan pesantren dalam menganalisis kehidupan sosial (Ansos), advokasi kepada yang lemah pada problem-problem yang terjadi di masyarakat, seperti keterbelakangan, kebodohan, kemiskinan, serta dekadensi social (Depag RI, 2005: 33).

Penelitian Lembaga Penelitian, Pendidikan, dan Penerangan Ekonomi dan Sosial (LP3ES) terhadap sejumlah pesantren di Jawa Barat pada pertengahan tahun 1970-an menunjukkan bahwa ternyata pesantren telah lama menjalankan peran sosial yang berpengaruh luas. Tugas kemasyarakatan pesantren tidaklah mengurangi arti tugas keagamaannya, karena peran tersebut merupakan penjabaran nilai-nilai hidup keagamaan bagi kemaslahatan masyarakat luas. Dengan tugas seperti ini pesantren akan menjadi milik bersama, didukung dan dipelihara oleh kalangan yang lebih luas serta akan berkesempatan melihat pelaksanaan nilai hidup keagamaan dalam kehidupan sehari-hari.

Dengan fungsi sosial ini, pesantren berhasil merespons persoalan-persoalan kemasyarakatan, seperti mengatasi kemiskinan, memelihara tali persaudaraan, mengurangi pengangguran, memberantas kebodohan, menciptakan kehidupan yang sehat, dan sebagainya. Menghilangkan kemiskinan bukan saja dengan menggembiarakan si miskin pada hari raya, atau memberikan uluran tangan saat mereka meminta, atau mengasuhnya di panti asuhan, melainkan membawa mereka pada kehidupan yang layak, memperpendek jurang kekayaan atau tindakan lainnya.

Potensi pesantren sebagai agen perubahan sosial di pedesaan memang sangat strategis. Di samping secara umum pesantren berada di tengah-tengah masyarakat, hubungan dengan masyarakat juga sangat dekat. Pesantren secara umum menjadi semacam tempat bertanya bagi masyarakat, tidak hanya dalam soal-soal keagamaan, tetapi juga sosial kemasyarakat. Itulah yang dikenal sebagai da'wah bil bal, yakni seruan kebajikan yang diwujudkan dalam tindakan nyata.

Pesantren An Nuqayah, Guluk-guluk, Sumenep Madura, justru sudah lebih awal melakukan usaha pengembangan masyarakat. Pada tahun 1981, pesantren yang berdiri tahun 1887 ini mendapatkan hadiah dan penghargaan Kalpataru karena prestasinya dalam 
'menyelamatkan lingkungan'. Penghargaan ini tidak hanya sebentuk pengakuan dari pemerintah, tetapi juga langsung dirasakan oleh masyarakat sekitarnya. Usaha yang dilakukan pesantren ini adalah penghijauan di perbukitan gundul dan di beberapa tempat di sepanjang tepian jalan. Akibatnya, masyarakat tidak lagi kesulitan air untuk kebutuhan sehari-hari.

Program ini hanya salah satu dari sekian banyak program pengembangan masyarakat yang dilakukan An Nuqayah. Dalam program ini, pesantren An Nuqayah bekerja sama dengan berbagai pihak baik yang diharapkan dapat memberikan bantuan dan konsultasi teknis maupun dengan pihak pemberi dana stimulan untuk pengembangan. Beberapa kegiatan yang telah dilakukan An Nuqayah antara lain meliputi usaha simpan pinjam, usaha bersama, pengadaan pupuk organik, usaha kesehatan masyarakat, hingga pengembangan teknologi tepat guna.

Usaha-usaha yang dilakukan pesantren-pesantren ini, yang secara umum menyentuh ranah kehidupan social, juga secara tidak langsung menyentuh pada hal pengembangan ekonomi masyarakat sekitarnya, yang dengan keberadaan pesantren sebagai sentral, berusaha membawa kehidupan ekonomi masyarakat sekitarnya kea rah yang lebih baik. Yang dulunya interaksi ekonomi ini hanya terjadi pada ksaran masyarakat menjadi pengada (penjual) barang-barang yang dibutuhkan oleh masyarakat pesantren, maka semakin lama berselangnya waktu, terjadi beberapa inovasi yang dilakukan oleh pesantren untuk memajukan masyarakat sekitarnya.

Pesantren Nurul Jadid, Paiton Probolinggo, Jawa Timur, adalah salah satu pesantren yang sejak awal 80-an sudah menjalankan upaya pengembangan masyarakat melalui Biro Pengembangan Pesantren dan Masyarakat (BPPM). Di samping melakukan pelatihanpelatihan bagi masyarakat, khsusnya mengenai industri tepat guna, BPPM juga mendampingi masyarakat dalam unit usaha kecil, seperti industri tahu, Industri tempe, kerajinan batik, konveksi, hingga, pertanian (agribisnis), dan perikanan.

Pesantren Maslakul Huda, Kajen, Pati, Jawa Tengah termasuk yang paling awal melakukan usaha pengembangan masyarakat di sekitar Kajen dan Pati pada umumnya. Bahkan, pada tahun 2005, da'wah bil hal yang dilakukan pesantren ini bersama masyarakat sudah mencapai Rp 22,5 miliar. Beberapa di antaranya adalah berupa Bank Perkreditan Rakyat (BPR) Artha Huda Abadi yang beraset puluhan miliar rupiah, unit simpan pinjam syariah (USPS), beberapa kelompok swadaya masyarakat (KSM) binaan, dan pembuatan pakan ternak dari limbah tapioka.

Tentu saja, unit usaha yang dikelola tidak serta-merta menjadi seperti sekarang. Ada proses panjang yang dimulai pada 1976, saat Biro Pengembangan Pesantren dan Masyarakat Pesantren Maslakul Huda (BPPM-PMH) terbentuk. Aktivitas itu diwujudkan dalam bentuk proyek baik yang berjangka terbatas maupun berkelanjutan. Sebagian dilaksanakan secara mandiri oleh BPPM-PMH, sebagian lainnya bekerja sama dengan pihak lain. Instansi dan lembaga yang pernah bekerja sama dengan BPPM-PMH, antara lain BKKBN, Depperindag, Depkop dan PPK, Bank Indonesia.

Usaha pengembangan masyarakat yang dilakukan tiga pesantren tersebut tidak hanya langsung dirasakan manfaatnya oleh masyarakat, tetapi juga menjadi semacam proyek percontohan bagi pesantren-pesantren lainnya dalam melakukan kegiatan yang sama. 
Kegiatan semacam ini bahkan tidak hanya dilakukan di pesantren-pesantren di Jawa, tetapi juga di luar Jawa. Bahkan ada sejumlah pesantren yang secara khusus mengembangkan jenis usaha yang spesifik bagi masyarakat.

Data yang dihimpun Perhimpunan Pengembangan Pesantren dan Masyarakat (P3M) menyebutkan, setidaknya ada sekitar 70-an pesantren di seluruh Indonesia yang mengembangkan unit usaha spesifik bagi masyarakat di sekitarnya, dengan beragam bidang garapan. Mereka antara lain menjalankan aktivitas seperti penghijauan, reboisasi hutan, pertanian, sayur-mayur, tambak, peternakan, genteng, mebel, hingga bentuk kegiatan yang jarang dilakukan pesantren pada umumnya, mulai dari menangani buruh, penderita gangguan jiwa, Pekerja Seks Komersial (PSK), hingga korban narkoba.

\section{PENUTUP}

Pesantren dengan ruh, sunnah dan kehidupan berasrama dengan kyai sebagai tokoh pokoknya dan masjid sebagai pusat lembaganya, merupakan suatu system pendidikan yang tersendiri dan mempunyai corak khusus. Di dalam ruh, sunnah dan kehidupan berasrama itulah antara lain letak kekhususan pondok sebagai suatu system pendidikan. Awalnya pesantren muncul sebagai sarana pembelajaran pendidikan agama Islam di desa atau dusun pinggiran, yang dimana kyai menjadi pusat ilmu sekaligus pengajar. Namun, seiring berkembangnya zaman, pesantren mulai berusaha "berbaur" dengan keadaan, tanpa meninggalkan esensi utamanya, yaitu memberikan pengajaran Agama Islam. Peran kyai yang awalnya sebagai pusat Ilmu sekaligus pengajar, muli diganti dengan guru dan pendamping; system pengajaran klasik dengan metode sorogan dan wetonan diperkaya dengan system pengajaran klasikal dengan berbagai metode pengajaran; materi yang dulunya hanya berkisar pada ilmu agama, diperkaya dengan ilmu umum, seni dan bahasa. Tentu tak semua pesantren mengalami perubahan seperti ini, namun, kebanyakan sudah mulai meremajakan diri.

Peranan pondok pesantren sebagai lembaga pendidikan Islam, sejalan dengan tujuan pendidikan agama dan keagamaan dalam peraturan pemerinta no. 55 tahun 2007 adalah untuk membentuk sikap iman dan sikap takwa pada diri peserta didik dengan berbagai treatment tertentu dalam proses pembelajarannya sehingga mampu untuk mencapai tujuan ini. Tujuan lainnya adalah menciptakan kader ulama yang berkualitas, hal ini merupakan pokok utama diadakannya pesantren.

Walaupun dalam perjalanannya jumlah ulama kharismatik dan dalam ilmunya semakin berkurang, juga proses kaderisasi jarang bisa menghasilkan ulama dengan kualifikasi tersebut, namun keberadaan pesantren yang diperkuat dengan posisinya sebagai salah satu lembaga keagamaan, rasa optimis akan lahirnya kharismatik pada saatnya akan terwujud. Pesantren sebagai lembaga pendidikan Islam tertua, juga tak bisa dipungkiri memberikan pengaruh signifikan di daerah tempat berdirinya pesantren; dimana lingkungan sekitar pesantren menjadi lingkungan yang agamis, juga dengan adanya beberapa pesantren yang mengembangkan proyek yang berorientasi pada pengembangan ekonomi, masyarakat di sekitar pesantren secara tidak langsung juga ikut merasakan dampak positif dengan adanya berbagai proyek tersebut. 


\section{REFERENSI}

Abd, A'la, 2006. Pembaruan Pesantren, Yogyakarta: Pustaka Pesantren.

Abdurrohim, 2014. Ideology Pendidikan Islam Pesantren, Disertasi.

Arifin, M, 1996. Filsafat Pendidikan Islam, Jakarta: Sinar Grafika Offshet. 1993. Ilmu Pendidikan Islam, Jakarta: Bumi Aksara.

Basyuni, Muhammad M, Pesantren Dan Pembangunan Karakter Bangsa, Disampaikan Pada Acara Silatuahmi Nasional Keluarga Besar Pondok Modern Gontor, November 2008

Bruissenen, Martin Van, 1940. NU Tradisi Relasi-Relasi Kuasa Pencarian Wacana Baru, Yogyakarta: Terj. Lkis.

Depag RI, 2005. Pedoman Pembinaan Pondok Pesantren Dan Madrasah Diniyah, Jakarta: Ditjen Binbag Islam. 2003. Pola Pengembangan Pondok Pesantren, Jakarta: Ditjen Binbag Islam.

Dhofier, Zamakhsyari, 1985. Tradisi Pesantren Studi Tentang Pandangan Hidup Kiyai, Jakarta: LP3ES.

Ginanjar Kartasasmita, Peran Pondok Pesantren Dalam Membangun Sumber Daya Manusia Yang Berkualitas, Disampaikan Pada Milad pondok Pesantren Al-Qur'an Al-Falah Ke-29.

Haedari, Amin, 2007. Perluasan Peran Pesantren, Artikel, Direktorat Pendidikan Diniyah dan Pondok Pesantren Departemen Agama, 07 November.

M. Dawam Raharjo dkk, 1995. Pesantren dan Pembaharuan, Jakarta: Pt. Pustaka Lp3es.

M.A, Muhaimin, 2011. Pemikiran Dan Aktualisasi Pengembangan Pendidikan Islam, Jakarta: Rajawali Pers.

Mansur, Mahfud Junaedi, 2005. Rekonstruksi Sejarah Pendidikan Islam Di Indonesia, Departemen Agama RI.

Muqodi, 2010. Pendidikan Islam Terpadu, Yogyakarta: Magnum.

Saridjo,Marwan, 1982. Sejarah Pondok Pesantren Di Indonesia, Jakarta: Dharma Bakti.

Shaleh, Abdul Ranchman, 2000. Pendidikan Agama Dan Keagamaan Visi, Misi, dan Aksi, Jakarta: PT. Gemawindu.

Suryadharma Ali, 2013. Paradigma Pesantren, Memperluas Horizon Kajian dan Aksi, Malang: Uin Maliki Press.

PP No. 55 Tahun 2007 Tentang Pendidikan Agama dan Keagamaan.

UU RI No. 20 Tahun 2003 Tentang Sistem Pendidikan Nasional. 